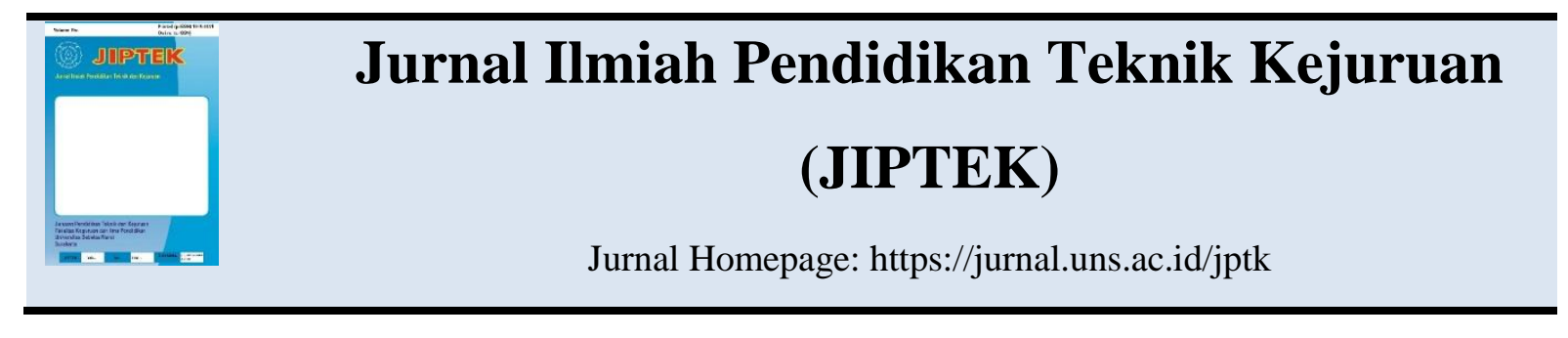

\title{
PENGARUH PROSES POST WELD HEAT TREATMENT (PWHT) PADA PENGELASAN MATERIAL PADUAN SUPER BERBASIS NIKEL DENGAN METODE TUNGSTEN INERT GAS (TIG) TERHADAP KEKERASAN DAN STRUKTUR MIKRO
}

\author{
Yahya Dwi Putra Nugraha, Suharno, Yuyun Estriyanto \\ Prodi Pendidikan Teknik Mesin, Fakultas Keguruan dan Ilmu Pendidikan, UNS \\ Kampus V UNS Pabelan, Jl. Ahmad Yani 200, Surakarta \\ E-mail: akunugraha84@gmail.com
}

\begin{abstract}
ABSTRAK
Penelitian ini bertujuan untuk: (1) mengetahui pengaruh proses Post Weld Heat Treatment $(P W H T)$ terhadap struktur mikro pada pengelasan material paduan super berbasis nikel $(\mathrm{Ni})$, (2) mengetahui pengaruh proses $P W H T$ terhadap kekerasan pada pengelasan material paduan super berbasis $\mathrm{Ni}$, (3) mengetahui $P W H T$ yang menghasilkan struktur mikro dan kekerasan paling optimal pada pengelasan material paduan super berbasis Ni. Penelitian ini menggunakan metode eksperimen. Sampel dalam penelitian ini adalah pengelasan material paduan super berbasis $\mathrm{Ni}$ menggunakan metode Tungsten Inert Gas (TIG) dengan penambahan $P W H T$. Proses pengelasan $T I G$ menggunakan variasi kuat arus sebesar $70 \mathrm{~A}, 80$ A, dan 100 A. Sedangkan proses $P W H T$ menggunakan variasi suhu yaitu $600^{\circ} \mathrm{C}, 700^{\circ} \mathrm{C}$, dan $800^{\circ} \mathrm{C}$. Analisis data menggunakan metode deskriptif kuantitatif dari hasil struktur mikro dan kekerasan. Data tersebut dianalisis menggunakan uji struktur mikro dan uji kekerasan dari hasil pengelasan material paduan super berbasis $\mathrm{Ni}$ menggunakan metode $T I G$ dengan penambahan $P W H T$. Hasil penelitian menunjukkan bahwa: (1) struktur mikro hasil pengelasan material paduan super berbasis Ni dengan kuat arus dan perlakuan $P W H T$ yang divariasikan terlihat berbeda-beda antara daerah las, daerah $H A Z$ dan daerah logam induk. Pengelasan dan PWHT pada suhu tinggi menimbulkan adanya butiran matrik $\gamma$ dan $\gamma^{\prime}$ presipitat yang berukuran kecil, halus dan tersebar merata di permukaan material, (2) terdapat perbedaan nilai kekerasan di daerah las, daerah $H A Z$ dan daerah logam induk pada setiap perlakuan pengelasan dengan kuat arus dan $P W H T$ yang divariasikan. Makin tinggi kuat arus dan $P W H T$ yang digunakan, makin seragam pula distribusi nilai kekerasan material, (3) perlakuan pengelasan dengan kuat arus sebesar 100 A dan $P W H T 800^{\circ} \mathrm{C}$ pada material paduan super berbasis $\mathrm{Ni}$ adalah yang paling optimal/baik, karena mampu menyeragamkan struktur mikro dan meratakan distribusi nilai kekerasan material tersebut.
\end{abstract}

Kata Kunci: kekerasan, paduan super berbasis nikel, $P W H T$, struktur mikro, $T I G$ 


\section{PENDAHULUAN}

Paduan super (Superalloys) adalah paduan yang dikembangkan untuk penggunaan material pada temperatur tinggi atau tahan panas. Paduan super umumnya mengandung nikel (Ni), besi $(\mathrm{Fe})$, kobalt $(\mathrm{Co})$, kromium (Cr) dan sejumlah wolfram (W), molibdenum (Mo), tantalum (Ta), niobium $(\mathrm{Nb})$, titanium $(\mathrm{Ti})$, serta alumunium $(\mathrm{Al})$ (Matthew \& Stephen, 2002). Material paduan super dapat digolongkan menjadi 3 yaitu paduan super berbasis besi, paduan super berbasis kobalt, dan paduan super berbasis nikel (Choudhury \& El-Baradie, 1998). Paduan super berbasis nikel banyak digunakan di dalam mesin pesawat terbang sebagai material sudu turbin karena memiliki kemampuan untuk mempertahankan kekuatan struktur (creep, fatigue) dan kestabilan permukaan (oksidasi, korosi) pada suhu tinggi (Mabruri, 2011). Menurut Segersall (2013: 10), paduan super berbasis nikel mempunyai nilai kekuatan tinggi dan memiliki ketahanan korosi pada suhu tinggi dengan suhu lelehnya mencapai $1.455^{\circ} \mathrm{C}$.

Salah satu aplikasi bahan paduan super digunakan dalam sudu turbin sebagai unit penambah daya atau Auxiliary Power Unit (APU) pada pesawat terbang. Sudu turbin yang beroperasi secara terus-menerus tentunya akan mengalami kerusakan seiring dengan meningkatnya pemakaian di dalam mesin pesawat terbang. Menurut Pedoman Pemeliharaan Pesawat, kecepatan turbin nominal roda $41.000 \mathrm{rpm}$, kecepatan operasi biasanya mencapai 101,3\%-102,5\%, dan temperatur operasi antara $566^{\circ} \mathrm{C}-650^{\circ} \mathrm{C}$. Pada umumnya setiap sudu turbin pesawat terbang memiliki risiko kerusakan berupa aus, retak ataupun patah. Menurut Suharno (2013), peristiwa patah melintang yang terjadi pada daerah ujung sudu turbin desebabkan oleh fraktur seketika. Hal ini disebabkan oleh adanya benturan dari sudu undeformed ke arah sudu berdekatan yang menyebabkan kerusakan roda turbin. Untuk mencegah kerusakan lebih parah perlu penggantian sudu turbin, akan tetapi apabila penggantian dinilai lebih mahal, patah yang terjadi sudu turbin dapat dilakukan pengelasan (welding). Dalam proses pengelasan akan didapat pemanasan yang tidak merata antara logam las, logam induk, dan daerah HAZ. Menurut Wiryosumarto \& Okumura (2008), panas pengelasan dapat mengakibatkan bagian yang dilas mengalami pengembangan termal. Perbedaan pemanasan menyebabkan terjadinya perubahan sifat atau struktur, metalurgi yang rumit, dan deformasi. Perubahan ini dapat mengurangi kekuatan sambungan las sehingga harus dihindari. Untuk itu perlu dilakukan perlakuan panas kembali untuk mengatur kembali struktur dari material. 
Post Weld Heat Treatment (PWHT) adalah salah satu jenis perlakuan panas yang paling banyak digunakan untuk pelepasan tegangan sisa (stress relief) pada benda yang mengalami proses pengelasan. $P W H T$ terdiri dari pemanasan bagian-bagian atau keseluruhan benda yang dilas ke dalam suatu temperatur yang tinggi dan mengalami holding selama beberapa waktu. Menurut Suharno et al (2012), proses PWHT dapat mengurangi tegangan sisa pada material yang mengalami pengelasan, mengurangi terjadinya kerusakan/retak dan mampu menyeragamkan struktur mikro, sehingga dapat memperbaiki kualitas suatu material. Hal ini juga sejalan dengan Sharma et al (2013) dan Prachya \& Poopat (2015), yang menyatakan bahwa proses $P W H T$ dapat mengurangi cacat akibat retak panas pasca pengelasan, mengurangi risiko terjadinya korosi, serta dapat meningkatkan ketangguhan material.

Penelitian ini bertujuan untuk: (1) mengetahui pengaruh proses PWHT terhadap struktur mikro pada pengelasan material paduan super berbasis nikel, (2) mengetahui pengaruh proses PWHT terhadap kekerasan pada pengelasan material paduan super berbasis nikel, (3) mengetahui PWHT yang menghasilkan struktur mikro dan kekerasan paling optimal pada pengelasan material paduan super berbasis nikel.

\section{METODE PENELITIAN}

Penelitian ini menggunakan metode eksperimen. Bahan dasar yang digunakan yaitu sudu turbin wheel Auxiliary Power Unit (APU) yang dipakai oleh pesawat Garuda Indonesia Boeng 737 yaitu material standar Superalloys Rene 95 (Nickel-Based Superalloys).

Alat yang digunakan dalam penelitian ini adalah mesin gerinda dan poles, mesin las Tungsten Inert Gas (TIG), penggores, mesin PWHT (oven pemanas listrik), alat uji kekerasan (Micro Hardness Vickers), alat uji struktur mikro (Metallurgical Microscope with Inverted).

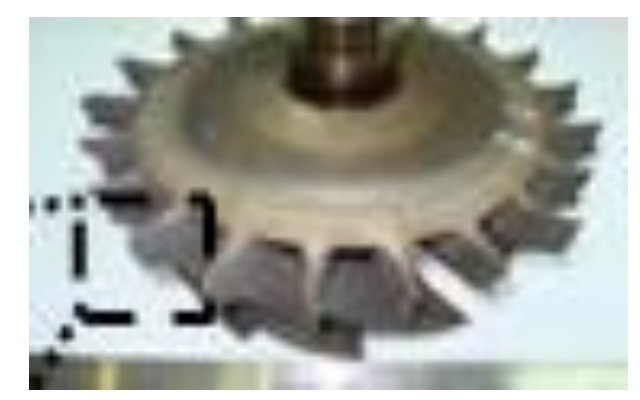

Gambar 1. Material Paduan Super Berbasis Nikel Bagian APU

Spesimen uji dari material paduan super berbasis nikel (Nickel-Based Superalloys) akan dilakukan proses pengelasan TIG. Filler metal yang digunakan sesuai dengan jenis bahan dasarnya dengan ukuran $90 \mathrm{~mm}$ x $2 \mathrm{~mm}$ x 2 mm. Kuat arus yang digunakan pada pengelasan ini bervariasi, yakni sebesar 70 A, 80 A, 100 A, arus DC. Pengelasan ini 
menggunakan tiga ukuran amper yang berbeda bertujuan untuk mengetahui perbedaan pengaruh amper terhadap hasil kekerasan dan struktur mikro. Pengelasan dilakukan dengan posisi pengelasan dibawah tangan dengan kecepatan 80-100 $\mathrm{mm} / \mathrm{menit}$. Sedangkan spesimen uji tes yang dipakai dalam penelitian ini berjumlah 9 buah yang berbentuk plat $(61 \mathrm{~mm} \times 15 \mathrm{~mm}$ x $3 \mathrm{~mm}$ ). Spesimen yang dibuat disiapkan dari sudu yang masih dalam kondisi baik.

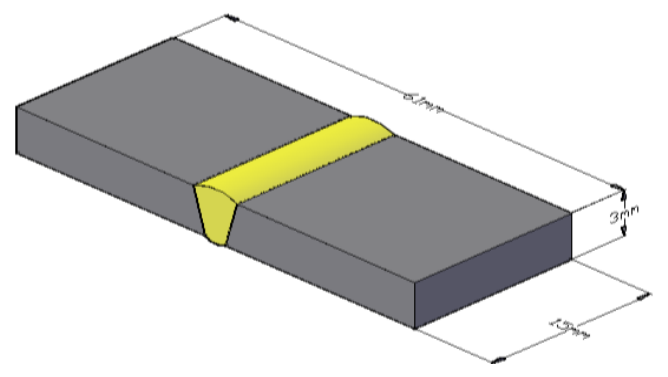

Gambar 2. Spesimen Uji Tes

Spesimen yang sudah jadi kemudian diberi perlakuan proses $P W H T$. Spesimen divariasikan untuk proses $P W H T 600^{\circ} \mathrm{C}$ selama $1 / 2$ jam, $P W H T 700^{\circ} \mathrm{C}$ selama $1 / 2$ jam dan $P W H T 800^{\circ} \mathrm{C}$ selama $1 / 2$ jam. Setelah proses $P W H T$ selesai, dilakukan pendinginan pada suhu kamar. Pengujian yang dilakukan dalam penelitian ini yaitu pengujian struktur mikro dan pengujian kekerasan pada daerah logam las, HAZ dan logam induk.

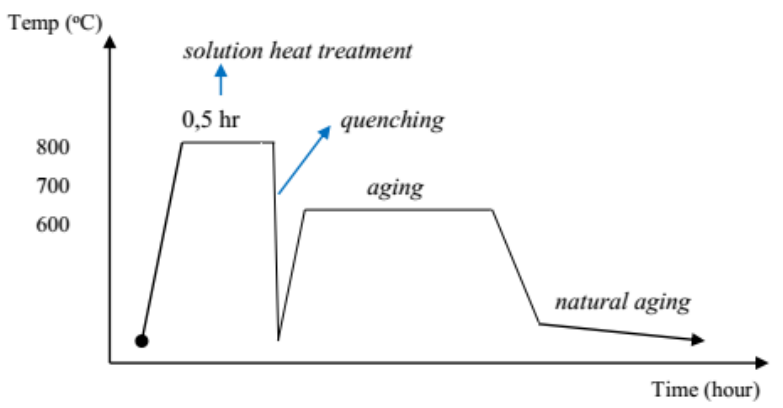

Gambar 3. Hubungan antara Suhu dan Waktu Perlakuan terhadap Material

\section{HASIL DAN PEMBAHASAN}

Berdasarkan hasil uji komposisi kimia yang telah dilakukan, diketahui bahwa material paduan super berbasis Ni (Superalloys Rene 95) memiliki 18 kandungan unsur kimia.

Tabel 1. Komposisi Kimia Material Paduan Super Berbasis Nikel

\begin{tabular}{cccc}
\hline \multicolumn{4}{c}{ Sampel Uji } \\
\hline \multicolumn{2}{c}{ Material Dasar } & \multicolumn{2}{c}{ Material Hasil } \\
\multicolumn{2}{c}{ Lasan } \\
\hline Unsur & Kandungan & Unsur & Kandungan \\
Kimia & $(\%)$ Berat & Kimia & $(\%)$ Berat \\
\hline $\mathrm{Ni}$ & 63,71798 & $\mathrm{Ni}$ & 61,93 \\
$\mathrm{C}$ & 0,12062 & $\mathrm{C}$ & 0,082 \\
$\mathrm{Si}$ & 0,01273 & $\mathrm{Si}$ & 0,009 \\
$\mathrm{~S}$ & 0,00864 & $\mathrm{~S}$ & 0,0089 \\
$\mathrm{P}$ & 0,00679 & $\mathrm{P}$ & 0,0083 \\
$\mathrm{Mn}$ & 0,2137 & $\mathrm{Mn}$ & 0,0207 \\
$\mathrm{Cr}$ & 12,49353 & $\mathrm{Cr}$ & 11,97 \\
$\mathrm{Mo}$ & 1,94892 & $\mathrm{Mo}$ & 1,99 \\
$\mathrm{~V}$ & 0,056 & $\mathrm{~V}$ & 0,047 \\
$\mathrm{Cu}$ & 0,02628 & $\mathrm{Cu}$ & 0,025 \\
$\mathrm{~W}$ & 4,28040 & $\mathrm{~W}$ & 4,11 \\
$\mathrm{Ti}$ & 4,05419 & $\mathrm{Ti}$ & 4,39 \\
$\mathrm{Co}$ & 9,07492 & $\mathrm{Co}$ & 8,94 \\
$\mathrm{Al}$ & 4,20357 & $\mathrm{Al}$ & 6,46 \\
$\mathrm{~B}$ & 0,01201 & $\mathrm{~B}$ & 0,0081 \\
$\mathrm{Nb}$ & 0,02693 & $\mathrm{Nb}$ & 0,026 \\
$\mathrm{Mg}$ & 0,01236 & $\mathrm{Mg}$ & 0,01 \\
$\mathrm{Sn}$ & 0,00281 & $\mathrm{Sn}$ & 0,0027 \\
\hline
\end{tabular}


Karakteristik umum dari material paduan super berbasis nikel (Superalloy Rene 95), yaitu material memiliki kekuatan dan stabilitas yang baik, mempunyai ketahanan terhadap oksidasi dan korosi panas yang baik, nilai konduktivitas panas tinggi, serta memiliki sifat mampu las yang baik.
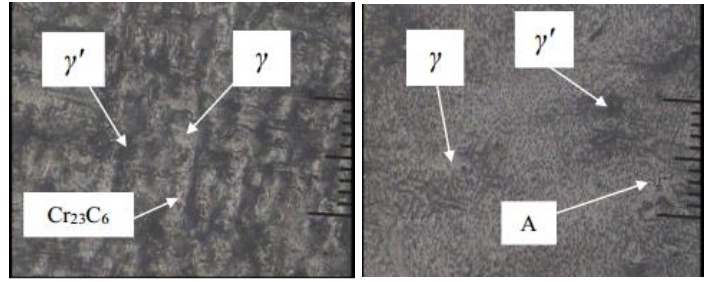

(a)

(b)

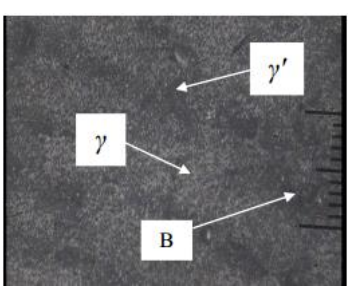

(c)

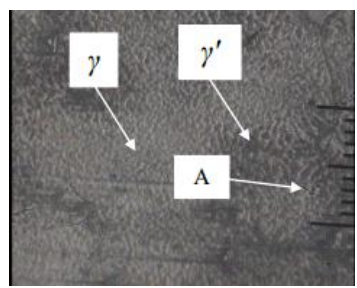

(e)

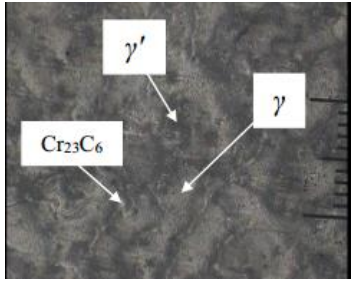

(g)

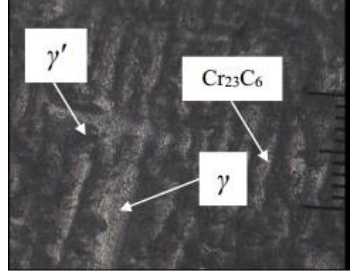

(d)

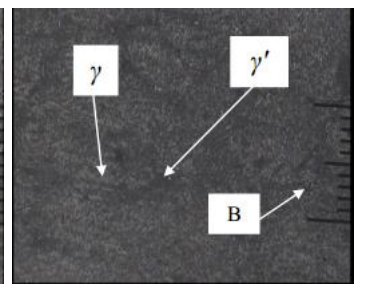

(f)

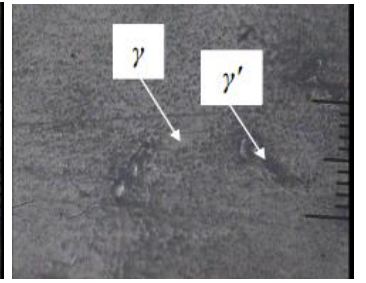

(h)

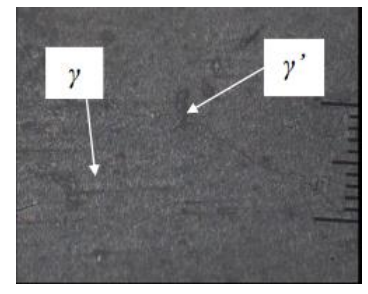

(i)
Gambar 4. Struktur Mikro Spesimen Paduan Super Berbasis Ni, (a) 70A-las, (b) 70A-HAZ, (c) 70A-logam induk, (d) 80A-las, (e) 80A-HAZ, (f) 80Alogam induk, (g) 100A-las, (h) 100A-HAZ, (i) 100A-logam induk, $P W H T 600^{\circ} \mathrm{C}$, perbesaran $200 \mathrm{X}$

Pengamatan struktur mikro pada spesimen uji telah dilakukan. Gambar (a) menunjukkan hasil struktur mikro daerah las pada material paduan super berbasis $\mathrm{Ni}$. Pada struktur miko tersebut memperlihatkan adanya kandungan fasa $\gamma$ (gamma matrix) dan $\gamma^{\prime}$ (gamma-prime precipitates). Ukuran partikel $\gamma$ dan $\gamma^{\prime}$ terlihat cukup jelas dan cukup besar. Selain itu, selama proses heat treatment berlangsung juga terdapat karbida $\mathrm{Cr}_{23} \mathrm{C}_{6}$ di dalam struktur mikro tersebut. Terbentuknya karbida $\mathrm{Cr}_{23} \mathrm{C}_{6}$ dikarenakan adanya pengaruh pengelasan. Karbida $\mathrm{Cr}_{23} \mathrm{C}_{6}$ memiliki peran penting dalam penguatan dengan menghambat pergerakan dislokasi. Karbida $\mathrm{Cr}_{23} \mathrm{C}_{6} \quad$ biasanya mengendap di batas butir dalam paduan yang kaya $\mathrm{Cr}$ sebagai partikel yang tidak teratur dan terputus-putus. Kondisi inilah yang membuat material paduan super berbasis $\mathrm{Ni}$ yang mengalami pengelasan dengan kuat arus $70 \mathrm{~A}$ dan $P W H T 600^{\circ} \mathrm{C}$ memiliki nilai kekerasan yang tinggi. Gambar (b), (e), dan (h) menunjukkan struktur mikro di daerah $H A Z$. Di daerah $H A Z$ terbentuk fasa $\gamma^{\prime}$ yang berukuran kecil dan lebih sedikit dibandingkan fasa $\gamma$. 
Butiran yang terbentuk di daerah $H A Z$ berupa fasa $\gamma$ mengalami peningkatan selama ekspansi.

Pengaruh suhu dan dengan waktu yang cukup menyebabkan dendrit terurai membentuk butir-butir fasa $\gamma$. Kondisi ini tentu menyebabkan daerah $H A Z$ memiliki nilai kekerasan yang lebih rendah dibandingkan di daerah las. Di sisi lain, struktur mikro di daerah $H A Z$ juga menunjukkan adanya retak/cacat (A) akibat pengelasan. Cacat las ini disebabkan oleh adanya retak panas selama proses pembekuan pasca pengelasn. Dari analisis terhadap struktur mikro yang ada dapat diperoleh bukti yang menunjukkan bahwa kekuatan sambungan las yang dilakukan sebelumnya adalah rendah.

Gambar (c), (f), (i) menunjukkan hasil struktur mikro di daerah logam induk. Persebaran fasa $\gamma^{\prime}$ yang terdapat pada struktur mikro tersebut mengalami peningkatan dan cenderung merata. Keadaan ini terjadi karena fasa $\gamma^{\prime}$ yang awalnya larut dalam batas butir berdifusi, sehingga mendekat dan membentuk precipitation hardening. Pada struktur mikro tersebut juga memperlihatkan kerusakan (B) berupa retak, pecah dan cacat plastis. Pada bagian (B) menunjukkan retak kecil bercabang yang tajam di sepanjang bagian. Tampilan retak (B) adalah jenis intergranular. Terjadinya retak ini diduga kuat disebabkan oleh proses pengerjaan pemesinan yang dapat menyebabkan terjadinya deformasi plastik pada bagian bawah permukaan.

Gambar (d) merupakan struktur mikro di daerah las 80 A yang memperlihatkan kecenderungan yang sama dengan daerah las 70 A. Hanya saja kandungan fasa $\gamma$ ' lebih banyak. Sementara daerah las $100 \mathrm{~A}$ (gambar g) menunjukkan hasil yang berbeda, dimana fasa $\gamma$ terlihat jelas, padat dan berukuran besar. Sedangkan fasa $\gamma$ ' sebagai penyokong kekuatan utama terlihat lebih sedikit tersebar di sekeliling matrik $\gamma$.

Uji struktur mikro pada spesimen dengan $P W H T \quad 700^{\circ} \mathrm{C}$ telah dilakukan. Gambar (j) menunjukkan hasil struktur mikro di daerah las $70 \mathrm{~A}, P W H T 700^{\circ} \mathrm{C}$. Struktur mikro tersebut terlihat berbeda dibandingkan dengan struktur mikro pada spesimen sebelumnya. Pada daerah las tersebut terbentuk wilayah dendritik dan wilayah interdendritik. Struktur wilayah dendritik kaya akan larutan padat fasa $\gamma$ (solid solution). Sedangkan struktur wilayah interdendritik terkonsentrasi elemen pembentuk karbida, $\mathrm{Nb}$ dan Mo (Tiago et $a l$, 2014). Adanya unsur Mo yang larut dalam $\gamma^{\prime}$ akan membantu efek pengerasn pada material tersebut. Terbentuknya struktur mikro seperti itu terjadi akibat adanya perlakuan yang telah diberikan pada 
material, seperti besar kuat arus pada saat pengelasan dan pengaruh temperatur $P W H T$ yang tinggi, sehingga dapat mempengaruhi batas butir. Hal ini sejalan dengan Prachya \& Poopat (2015), yang menyatakan bahwa pengaruh suhu yang tinggi dapat mempengaruhi ukuran batas butir dan nilai kekerasan material. Struktur mikro di daerah las 80 A (gambar $\mathrm{m}$ ) dan daerah las 100 A (gambar p) juga memperlihatkan kecenderungan yang sama, hanya saja ukuran fasa $\gamma$ dan $\gamma^{\prime}$ terlihat lebih kecil dan rapat.

Gambar (k) memeperlihatkan struktur mikro di daerah HAZ 70 A. Struktur mikro tersebut cenderung terlihat kasar. Batas butir di dalam struktur mikro tersebut terlihat kecil. Di permukaan daerah $H A Z$ terlihat $\gamma$ ' presipitat yang tersebar di matrik. Menurut Miroslav et al (2010), persebaran $\gamma^{\prime}$ presipitat dapat menghambat pergerakan dislokasi di dalam matrik, oleh karena itu kondisi tersebut dapat berkontribusi dan memberi keuntungan pada kekutan material. Hal yang sama juga ditunjukkan oleh hasil struktur mikro daerah logam induk $70 \mathrm{~A}$ (gambar 1).

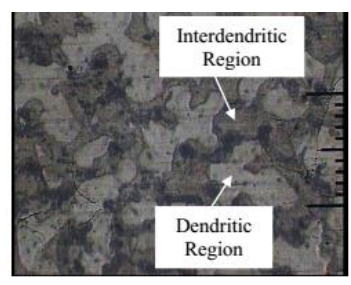

(j)

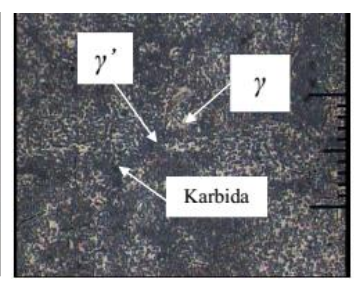

(k)

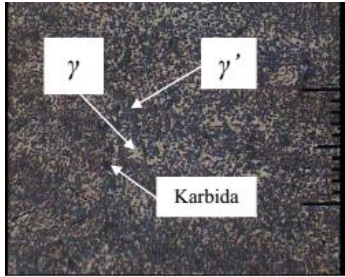

(1)

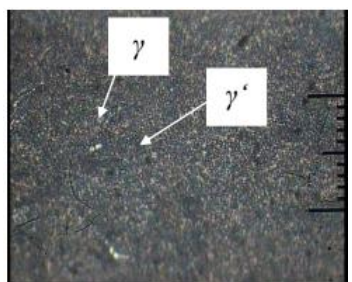

(n)

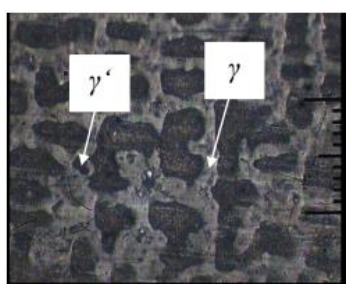

(p)

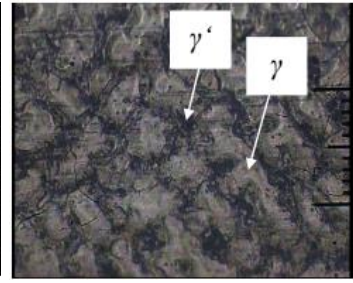

(m)

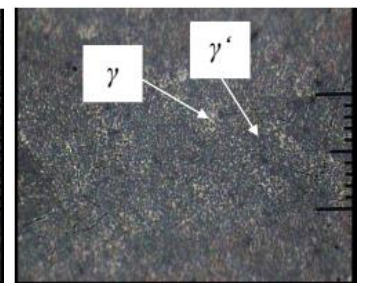

(o)

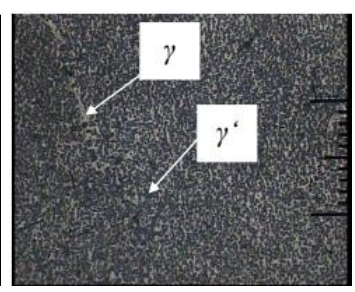

(q)

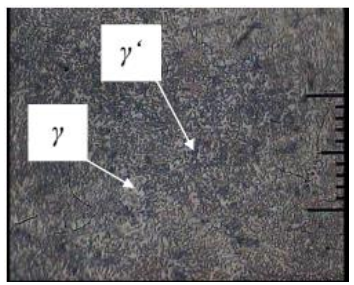

(r)

Gambar 5. Struktur Mikro Spesimen Paduan Super Berbasis Ni, (j) 70A-las, (k) 70A-HAZ, (1) 70A-logam induk, (m) 80A-las, (n) 80A-HAZ, (o) 80Alogam induk, (p) 100A-las, (q) 100A-HAZ, (r) 100A-logam induk, $P W H T 700^{\circ} \mathrm{C}$, perbesaran $200 \mathrm{X}$

Gambar (1) tidak mengalami perubahan yang signifikan dan cenderung mirip di daerah $H A Z$ (gambar k). Keadaan ini terjadi karena adanya pengaruh temperatur tinggi pada proses PWHT, sehingga struktur mikro yang terbentuk terlihat homogen. Gambar 
memperlihatkan struktur mikro di daerah $H A Z 80$ A. Struktur mikro di daerah $H A Z$ terlihat lebih halus, ukuran butir matrik $\gamma$ dan $\gamma^{\prime}$ presipitat sangat kecil tersebar merata di permukaan $H A Z$. Hal yang sama juga terjadi di daerah logam induk $80 \mathrm{~A}$ (gambar o). Struktur mikro di logam induk tidak mengalami perubahan yang signifikan. Sementara itu, struktur mikro di daerah $H A Z$ 100 A (gambar q) juga memiliki kecenderungan yang sama dengan daerah $H A Z 80 \mathrm{~A}$, hanya saja batas butir antara fasa $\gamma$ dan $\gamma^{\prime}$ di daerah HAZ 100 A terlihat cukup jelas. Pada daerah logam induk 100 A (gambar r) juga menunjukkan bentuk struktur mikro yang cenderung sama.

Gambar (s) merupakan struktur mikro di daerah las $70 \mathrm{~A}, P W H T 800^{\circ} \mathrm{C}$. Terdapat perbedaan dengan struktur mikro pada $P W H T 600^{\circ} \mathrm{C}$ dan $700^{\circ} \mathrm{C}$. Di daerah las 70 A, PWHT $800^{\circ} \mathrm{C}$ terbentuk butiran matrik $\gamma$ yang sangat dominan. Bentuk butiran matrik $\gamma$ terlihat cukup besar, halus dan tersebar merata.

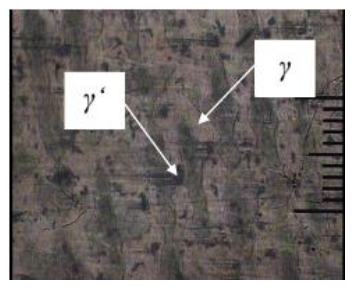

(s)

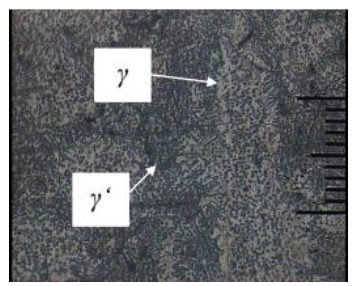

JIPTEK, Vol. X No. 2, Juli 2017 (u)

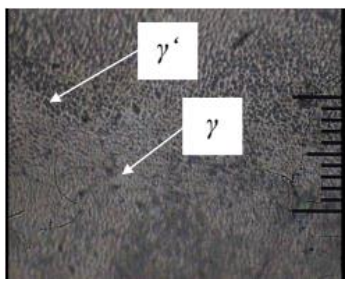

(w)

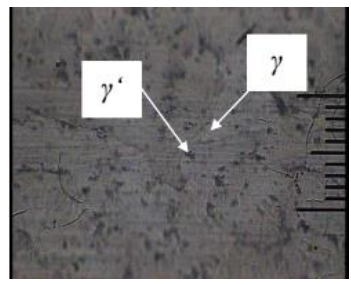

(y) (v)

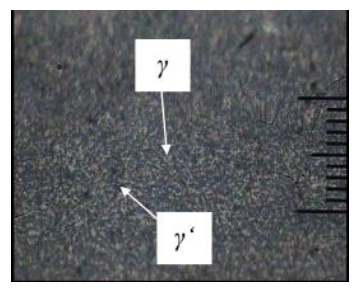

(x)

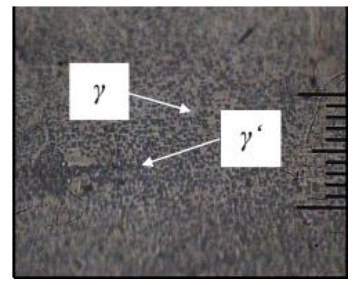

(z)

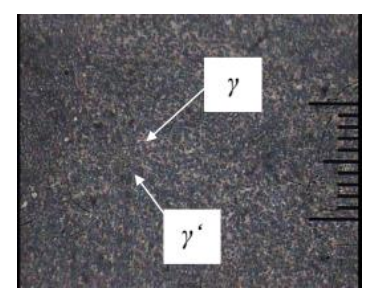

(z1)
Gambar 6. Struktur Mikro Spesimen Paduan Super Berbasis Ni, (s) 70A-las, (t) 70A-HAZ, (u) 70A-logam induk, (v) 80A-las, (w) 80A-HAZ, (x) 80Alogam induk, (y) 100A-las, (z) 100A-HAZ, (z1) 100A-logam induk, $P W H T 800^{\circ} \mathrm{C}$, perbesaran $200 \mathrm{X}$

Batas butir yang terbentuk tidak terlalu jelas karena dipengaruhi oleh banyaknya matrik $\gamma$ yang tersebar di daerah las. Fasa $\gamma^{\prime}$ presipitat yang tersebar di matrik $\gamma$ sangat sedikit. Hal ini disebabkan oleh efek panas yang ditimbulkan dari pengelasan serta perlakuan $P W H T$ dengan suhu yang tinggi. Suhu yang tinggi ini mampu membantu menyeragamkan struktur mikro.

Gambar (t) memperlihatkan struktur mikro di daerah $H A Z 70$ A. Terdapat perbedaan antara struktur mikro di daerah

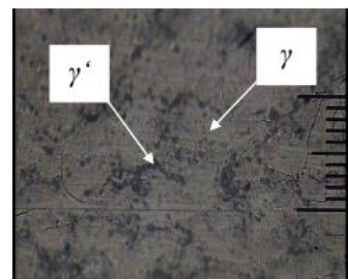


$H A Z$ dengan di daerah las. Ukuran matrik $\gamma$ terlihat lebih kecil dan cenderung lembut. Sedangkan struktur mikro di daerah logam induk (gambar u) menunjukkan bentuk yang berbeda. Di daerah logam induk terbentuk struktur mikro lebih kasar dibandingkan dengan di daerah las ataupun HAZ. Gambar (v) merupakan bentuk struktur mikro di daerah las. Spesimen yang mengalami pengelasan dengan kuat arus sebesar $80 \mathrm{~A}$ dan $P W H T 800^{\circ} \mathrm{C}$ ini memiliki struktur mikro yang lebih halus. Batas butir yang terbentuk di daerah las tidak terlihat jelas. Hal ini disebabkan oleh adanya pengaruh besarnya kuat arus pada pengelasan dan temperatur $P W H T$ yang tinggi. Matrik $\gamma$ yang sangat dominan dan tersebar merata di permukaan las. Matrik $\gamma$ terlihat lebih jelas dan padat. Di daerah matrik $\gamma$ juga terdapat fasa $\gamma^{\prime}$ presipitat yang terlihat kecil. Keadaan ini juga cenderung sama dengan struktur mikro di HAZ (gambar w). Perbedaan yang terjadi hanya pada ukuran butiran matrik $\gamma$ dan fasa $\gamma^{\prime}$ presipitat. Struktur mikro di logam induk (gambar $\mathrm{x}$ ) terlihat lebih gelap, hal ini dikarenakan fasa $\gamma$ ' presipitat yang terbentuk di daerah tersebut lebih banyak dibandingkan matrik $\gamma$. Gambar (y) merupakan struktur mikro di daerah las yang mengalami pengelasan dengan kuat arus $100 \mathrm{~A}$ dan $P W H T 800^{\circ} \mathrm{C}$. Matrik $\gamma$ yang terbentuk di daerah las terlihat banyak dan tersebar merata ke seluruh permukaan daerah las. Butiran matrik $\gamma$ terlihat jelas dan padat. Batas butir yang terbentuk tidak terlihat jelas karena pengaruh dominasi matrik $\gamma$ yang sangat tinggi. Di daerah las juga terbentuk fasa $\gamma^{\prime}$ presipitat yang bertebaran di matrik $\gamma$. Butiran fasa $\gamma^{\prime}$ presipitat berukuran kecil, lembut dan cukup banyak. Gambar (z) adalah bentuk struktur mikro di daerah HAZ. Di daerah $H A Z$, fasa $\gamma^{\prime}$ presipitat terlihat lebih banyak jika dibandingkan dengan struktur mikro di daerah las. Kondisi yang sama juga dapat dilihat pada struktur mikro di logam induk (gambar z1). Struktur mikro di logam induk tidak mengalami perubahan yang signifikan, hanya saja memiliki perbedaan pada ukuran butir yang terkandung. Ukuran butiran matrik $\gamma$ dan fasa $\gamma^{\prime}$ presipitat lebih kecil dibandingkan dengan ukuran butiran di daerah HAZ. Kondisi ini membuktikan bahwa pengelasan menggunakan kuat arus sebesar 100 A dan PWHT $800^{\circ} \mathrm{C}$ telah mampu menyeragamkan struktur mikro. Hal ini juga berpengaruh pada meratanya distribusi kekerasan bahan.

Uji kekerasan dilakukan setelah struktur mikro diketahui. Tujuan dari pengujian ini adalah untuk mengetahui distribusi kekerasan pada material paduan super berbasis nikel setelah dilakukan pengelasan dan proses $P W H T$.

Berdasarkan hasil uji kekerasan yang telah dilakukan, terlihat adanya perbedaan 
yang cukup signifikan antara nilai kekerasan pada spesimen uji yang diberi PWHT $600^{\circ} \mathrm{C}, 700^{\circ} \mathrm{C}$, dan $800^{\circ} \mathrm{C}$. Distribusi nilai kekerasan yang terbaik pada spesimen ini yaitu yang mendapat perlakuan pengelasan dengan kuat arus sebesar $100 \mathrm{~A}$ dan PWHT $800^{\circ} \mathrm{C}$ (gambar c1). Rata-rata nilai kekerasan yang menggunakan perlakuan tersebut yaitu sebesar 539,1 VHN (535 VHN di daerah las, 569,8 VHN di $H A Z, 512,5$ $V H N$ di logam induk). Perlakuan tersebut dinilai berhasil meratakan distribusi nilai kekerasan dan menyeragamkan butir kristal (struktur mikro) material paduan super berbasis nikel.
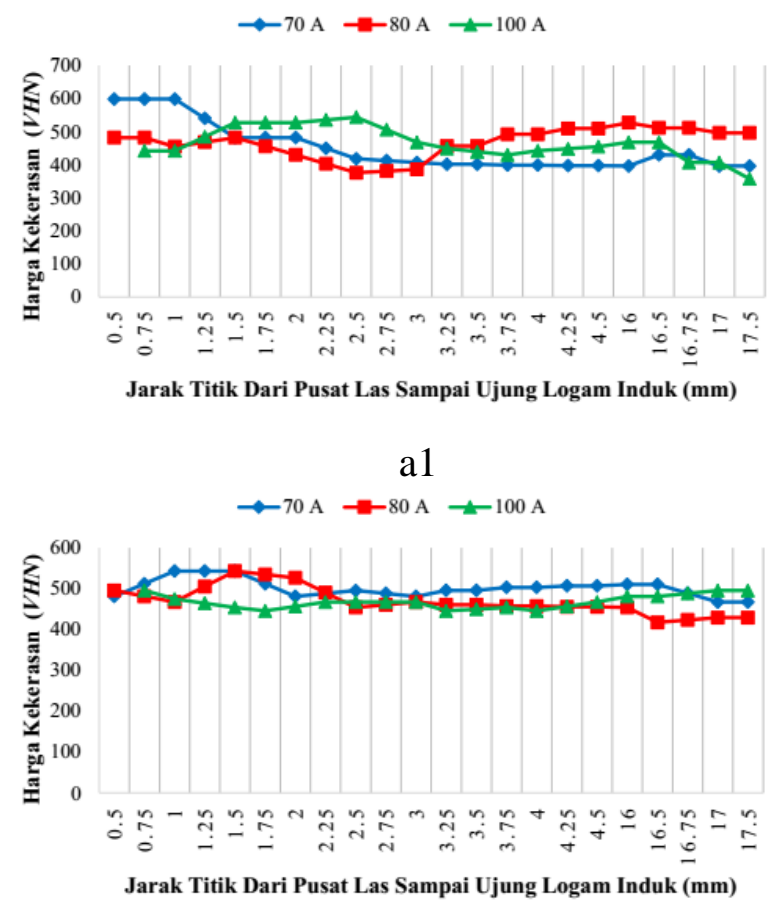

b1

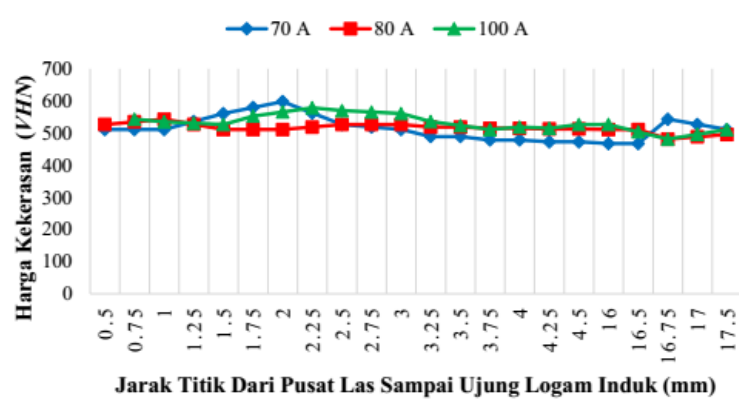

c1

Gambar 7. Grafik Kekerasan Paduan Super Berbasis Nikel, (a1) PWHT $600^{\circ} \mathrm{C}$, (b1) $P W H T \quad 700^{\circ} \mathrm{C}$, (c1) $P W H T$ $800^{\circ} \mathrm{C}$

\section{SIMPULAN DAN SARAN}

Material paduan super berbasis Nikel (Ni) yang mengalami pengelasan $T I G$ dengan besar kuat arus dan PWHT yang divariasikan memiliki pengaruh terhadap struktur mikro dan kekerasan. Hasil penelitian menunjukkan bahwa makin besar kuat arus dan makin tinggi suhu PWHT yang diberikan, maka makin baik pula perlakuan tersebut untuk menyeragamkan struktur mikro dan meratakan distribusi nilai kekerasan material. Struktur mikro yang seragam dibuktikan dengan adanya butiran matrik $\gamma$ dan fasa $\gamma^{\prime}$ presipitat yang halus dan tersebar merata di daerah las, $H A Z$ serta logam induk. Selain itu, batas butir yang terbentuk pada struktur mikro tidak terlihat jelas. Distribusi nilai kekerasan yang paling merata pada spesimen ini yaitu yang mendapatkan perlakuan pengelasan dengan kuat arus sebesar 100 A dan $P W H T 800^{\circ} \mathrm{C}$. Rata-rata nilai kekerasannya yaitu sebesar 539,1 VHN. Struktur mikro yang seragam 
serta distribusi nilai kekerasan yang merata mampu meningkatkan kualitas material menjadi lebih baik.

Saran untuk penelitian selanjutnya perlu dilakukan proses $P W H T$ dengan suhu yang lebih tinggi untuk mengetahui karakteristik mekanik yang lebih baik. Selain itu, perlu dilakukan pengamatan struktur mikro dengan perbesaran yang lebih besar atau menggunakan pengujian Scanning Electron Microscopy (SEM) dan/atau Energy Dispersive X-Ray (EDX) supaya struktur mikro yang diamati dapat terlihat lebih jelas, sehingga proses menganalisis fenomena yang ada pada material lebih maksimal.

\section{DAFTAR PUSTAKA}

Anonim. (2008). Maintenance Manual (MM), Seattle: Boeing Co, ATA 4941-00, 1-5, ATA 49-00-00, 102, ATA 49-11-00, 207-213.

Choudhury, I. A. \& El-Baradie, M. A. (1998). Machinability of Nickel-Base Superalloys: a General Review. Journals of Materials Processing Technology. Vol. 77, pp. 278-284.

Mabruri, E. (2011). Peranan Unsur Refraktori di dalam Nickel-Based Superalloys: Suatu Review. Majalah Metalurgi. V 26.2, ISSN: 0126-3188, pp. 67-68.

Matthew J. \& Stephen J. Donachie. (2002). Superalloys A Technical Guide Second Edition. USA: ASM International.

Miroslav, S., Karel, O., Martin, P., Jaroslav, P., \& Karel, H. (2010). Fatigue Properties of Nickel-Base Superalloy
Inconel 792-5a at $800^{\circ} \mathrm{C}$. Journal of Metal, Ceska Republika.

Prachya P. \& Poopat, B. (2015). Investigation into The Influence of Post Weld Heat Treatment on The Microstructure and Hardness of Inconel X-750. Journal of Advances in Mechanical Engineering, pp. 1-11.

Segersall, M. (2013). Nickel-Based SingleCrystal Superalloy. Linköping Studies in Science and Technology Licentiate Thesis No. 1568, ISBN: 978-91-7519709-8, ISSN: 0280-7971.

Sharma, S. D., Saluja R., \& Moeed, K. M. (2013). A Review on Effect of Preheating and/or Post Weld Heat Treatment (PWHT) on Hardened Steel. International Journal of Technical Research and Applications, Vol. 1, Issue 2, pp. 05-07.

Suharno, Sugiyanto, A., Estriyanto, Y., \& Harjanto, B. (2013). Analisis Kegagalan Retak dan Teknologi Perbaikan Sudu Turbin Jenis Inconel 792 pada Pesawat Terbang. Jurnal Teknik Mesin, Vol 14, No. 1, ISSN 1410-9867.

Suharno, Sugyianto A., Buntario R. E., Widagdo D., Estriyanto Y., \& Harjanto B. (2012). Advantage of SWET Technique on Joining Inconel 792 Material. Global Journal of Researches in Engineering Mechanical and Mechanics Engineering, Vol. 12, Issue 6, ISSN: 2249-4596.

Tiago, J. A., Rodrigo, M. G. P., \& Ana, S. C. M. (2014). Impact of dilution on the Microstructure and Properties of Ni-Based 625 Alloy Coatings. Soldag. Insp. Sao Paulo, Vol. 19, No. 02, p. 134-144.

Wiryosumarto, H. \& Okumura, T. (2008). Teknologi Pengelasan Logam. Jakarta: PT. Pradnya Paramita. 